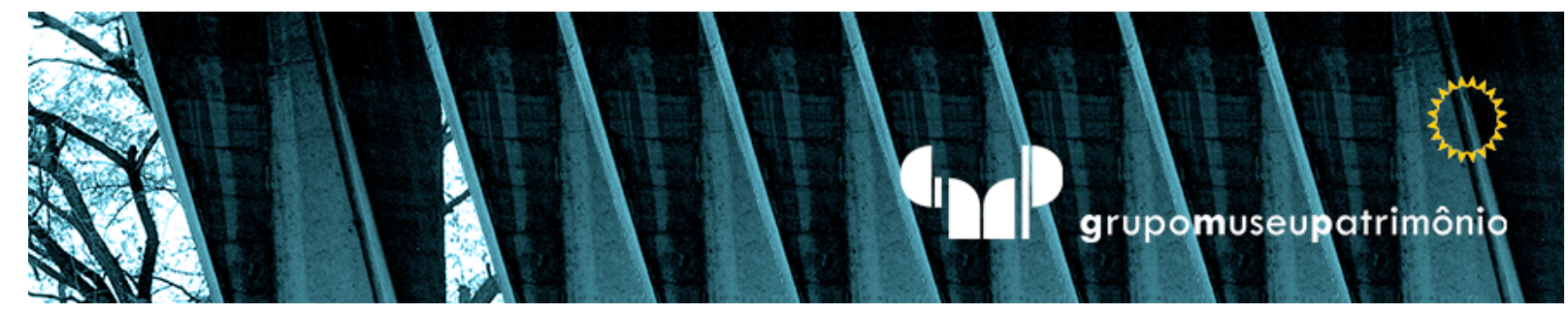

\title{
A impermanência da imagem na obra de Lais Myrrha
}

\section{La impermanência de la imagen en la obra de Lais Myrrha;}

\section{The impermanence of the image in the work of Lais Myrrha}

\section{Letícia Becker Savastano}

FAU-USP, São Paulo, Brasil. leticia.savastano@usp.br 


\section{Resumo}

Apostando na capacidade artística de alargar possibilidades de imaginação e narrativas, este ensaio discorre sobre uma série de obras da artista brasileira Lais Myrrha: Mitos de Origem (2012), Teoria das Bordas (2007), o Passo da História (2014), Dicionário do Impossível (2005), Descontinuidade pelo Tempo (2017) e Cálculo das diferenças (2017). A seleção se da por serem expressões imagéticas que dialogam com a materialidade das coisas ao mesmo tempo que expõe a linha de raciocínio (ou parte dela) da artista com o objetivo de deslocar discursos e elementos conceituais aparentemente cristalizados enquanto narrativas incontestadas como, por exemplo, o tempo e o conceito de história.

Palavras-Chave: Arte Contemporânea. Arte Historiográifca. Imagem. Narrativas. Imaginários.

\section{Resumen}

Considerando la capacidad artística para ampliar possobilidades de imaginación y narrativas, este ensayo discute una serie de trabajos de la artista brasileña Lais Myrrha: Mitos de Origen (2012), Teoria de Iss bordes (2007), EI paso de la historia (2014), Diccionario de lo imposible (2005), Discontinuidad de tiempo (2017) y Ccálculo de diferencia (2017). La selección sucede porque son expresiones de imágenes que dialogan la materialidade de las cosas mientas exponen parte de la línea de razonamiento de la artista para desplazar discursos y elementos conpetuales aparentemente cristalizados como narraciones indiscutibles como, por ejemplo, el tiempo y el concepto de historia.

Palavras-Clave: Arte contemporanea. Arte historiografica. Imagen. Narrativa. Imaginario.

\section{Abstract}

Pointing to the artistic capacity to expand possibilities of imagination and narratives, this essay discusses a series of works made by the contemporary artist Lais Myrrha. The commented works will be Myths of Origin (2012) , Borters Theory (2007), The March of History (2014), Dictionary of the impossible (2005), Descontinuity though time (2017), Differences of Calculation (2017). This works was selecteds because they are imagetic expressions that dialogue with the materiality of things at the same time that they exposes part of the line of reasoning of the artist with the aim of displacing discourses and conceptual elements apparently crystallized as uncontested narratives such as time and the concept of history.

Keywords: Contemporary art. Histriographical art. Image. Narratives. Imaginary 


\section{PRÓLOGO: DUAS IMAGENS SE DESDOBRAM INFINTAS}

0.1

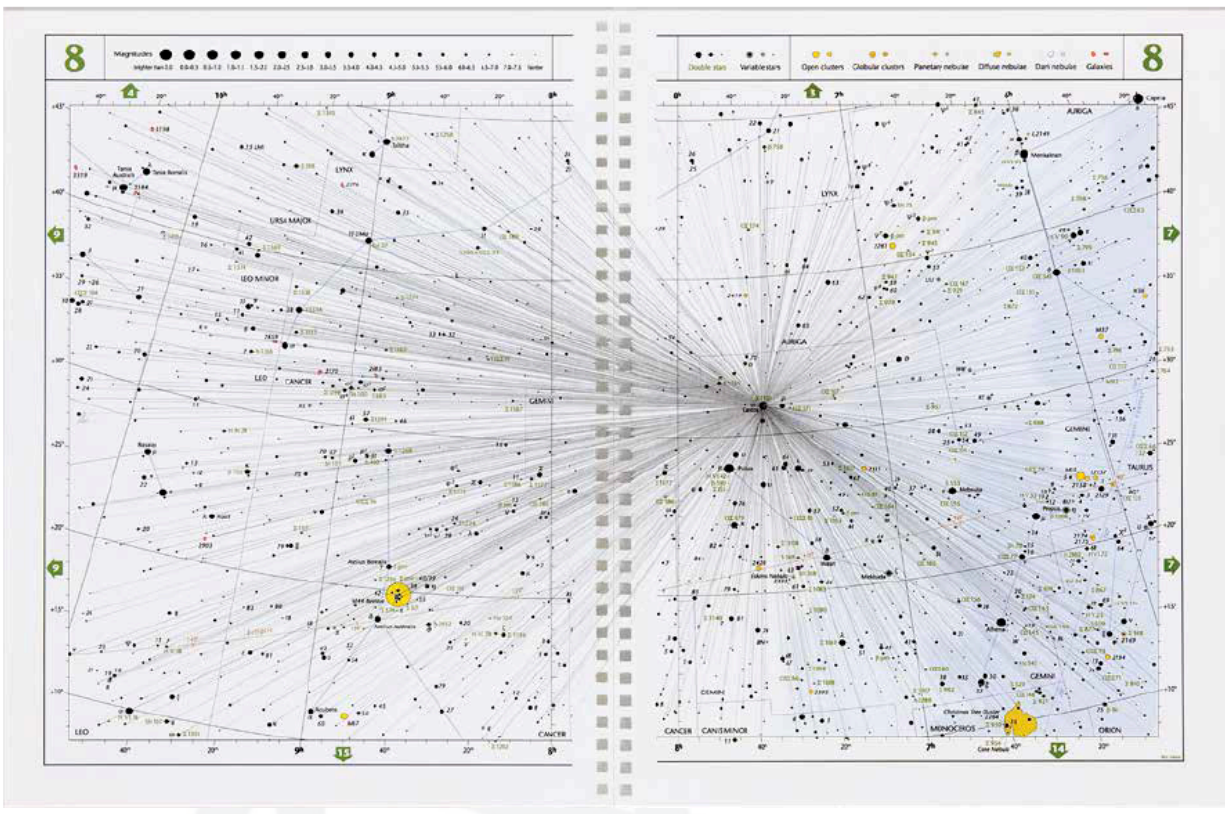



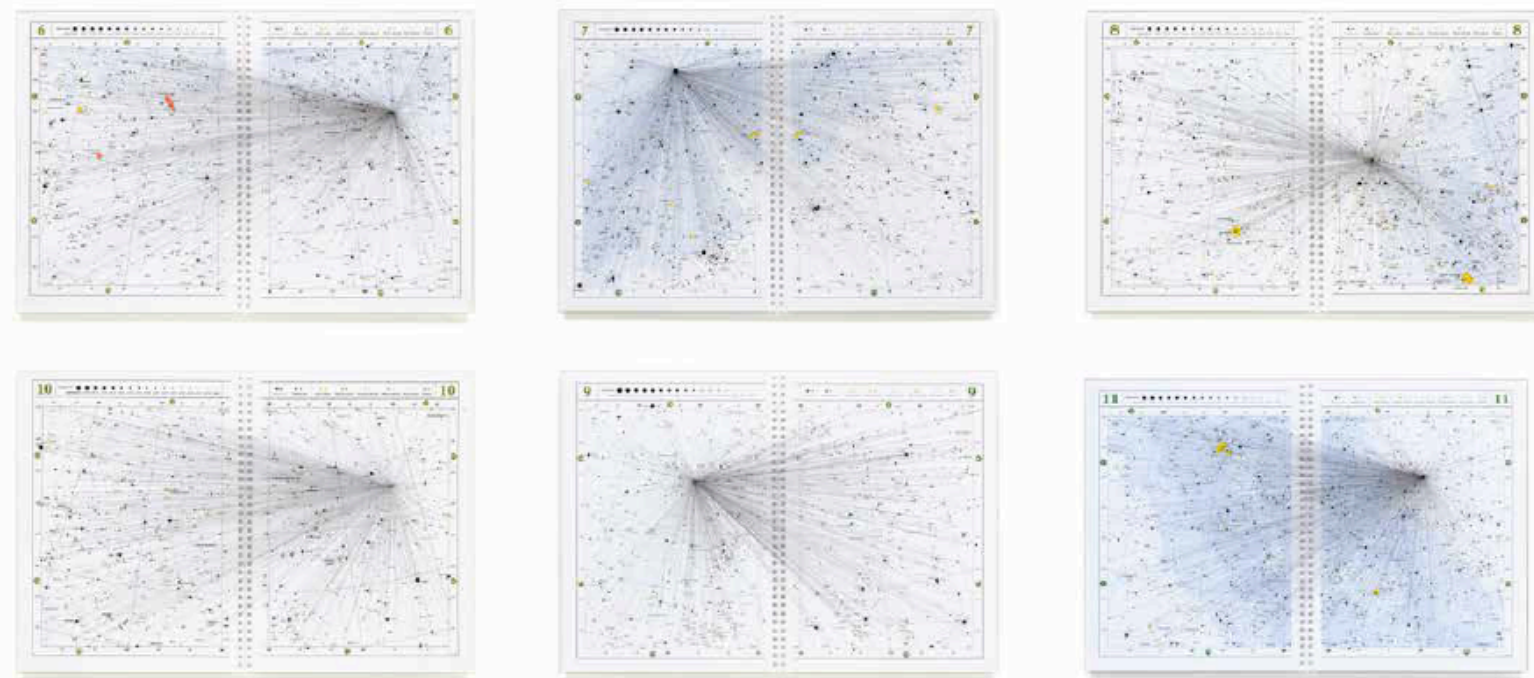

Figura 1 e 2: Mitos de Origem, 2012 Fonte: Portfólio Lais Myrrha. Imagens de Everton Ballardin

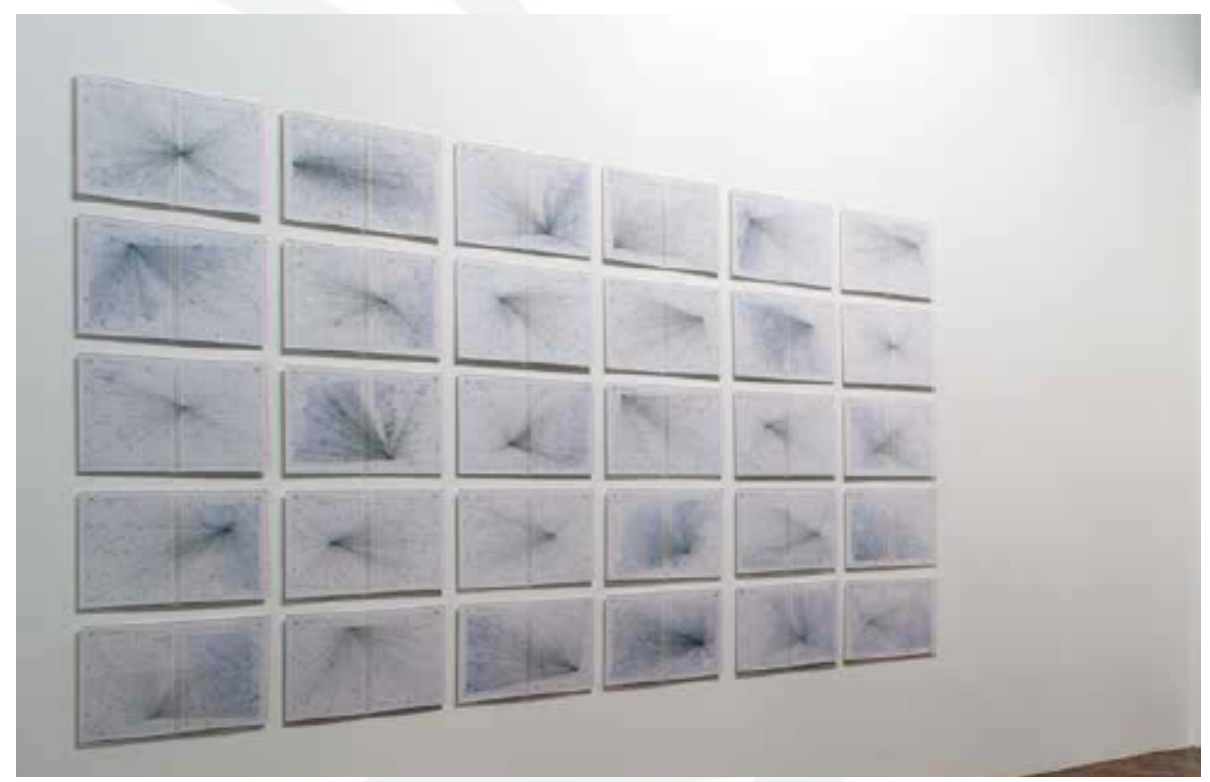

Figura 3: Mitos de Origem, 2012 Fonte: Portfólio Lais Myrrha. Imagem de Fernando Cohen 
rinta desenhos sobre trinta cartografias celestes. Em cada uma dessas cartografias uma estrela diferente é o ponto de onde irradiam linhas de grafite conectando-a às outras estrelas. Irradiações, estas, que podem ser lampejos de alegria, desejos, dor, amizade, guerra, morte, sofrimento, entre outras mais diversas emoções. Cada estrela pode ser a fundadora dentro de um sistema onde todas estão energeticamente imbricadas (REBOUÇAS, 2013, p.10) e, pensar essas possíveis representações trazem à tona considerações Benjaminianas de que as constelações, os conjuntos das estrelas, não são formações naturais, e sim imagens culturais. Tais quais são as cartografias.

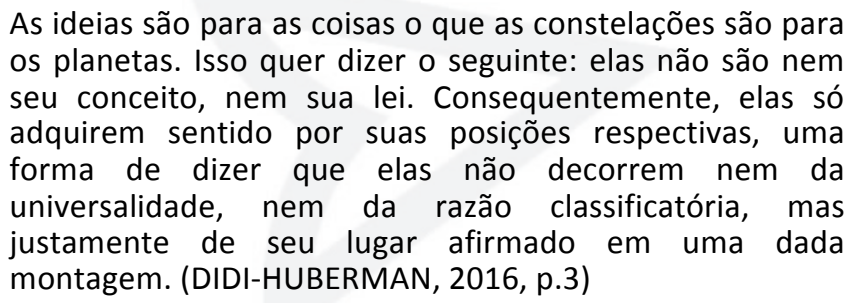

A montagem é um procedimento que pressupõe a desmontagem, e vice versa.

As coisas só aparecem aí ao tomarem posição, elas só se mostram aí ao se desmontar inicialmente (DIDI-HUBERMAN, 2016, p.1). A obra Mitos de Origem (2012) de Lais Myrrha dispõe de pelo menos seis possibilidades de montagem para a apresentação das cartografias (cada qual uma das infinitas configurações possíveis das conexões estelares). Para além da configuração em que são apresentados todos juntos (como na figura 3), os mapas podem ser agrupadas enquanto: Polo norte (do mapa 1 ao mapa 5); Trópico de Câncer ( mapas 6 ao 11); Equador (mapas 12 ao 19); Trópico de Capricórnio (mapas 20 ao 25); e Polo Sul (mapas 26 ao 30). São diversas, portanto, as possibilidades narrativas. Diferentes pontos de vista fazendo iluminar novas ideias como variados frames - enquadramentos- das configurações possíveis do céu, do passado aqui e agora.

Assim, as imagens podem ser compreendidas como um fenômeno originário que, reunindo representação e apresentação, são imagens-dialética segundo Georges Didi-Huberman (2015) que, em diálogo com Walter Benjamin, discorre 
sobre a potência de a imagem reunir o devir daquilo que muda e daquilo que permanece. A imagem fulgura, ocasiona luz, arde. A imagem, como uma estrela, é uma bola de fogo que atravessa o horizonte do passado. Mas, estando junto da potência a fragilidade, eis o mito de origem: "[...] disso tudo, uma vez que visíveis, as coisas são condenadas a remergulhar quase imediatamente na escuridão de seu desaparecimento (DIDI-HUBERMAN, 2015, p.12)

\section{2}

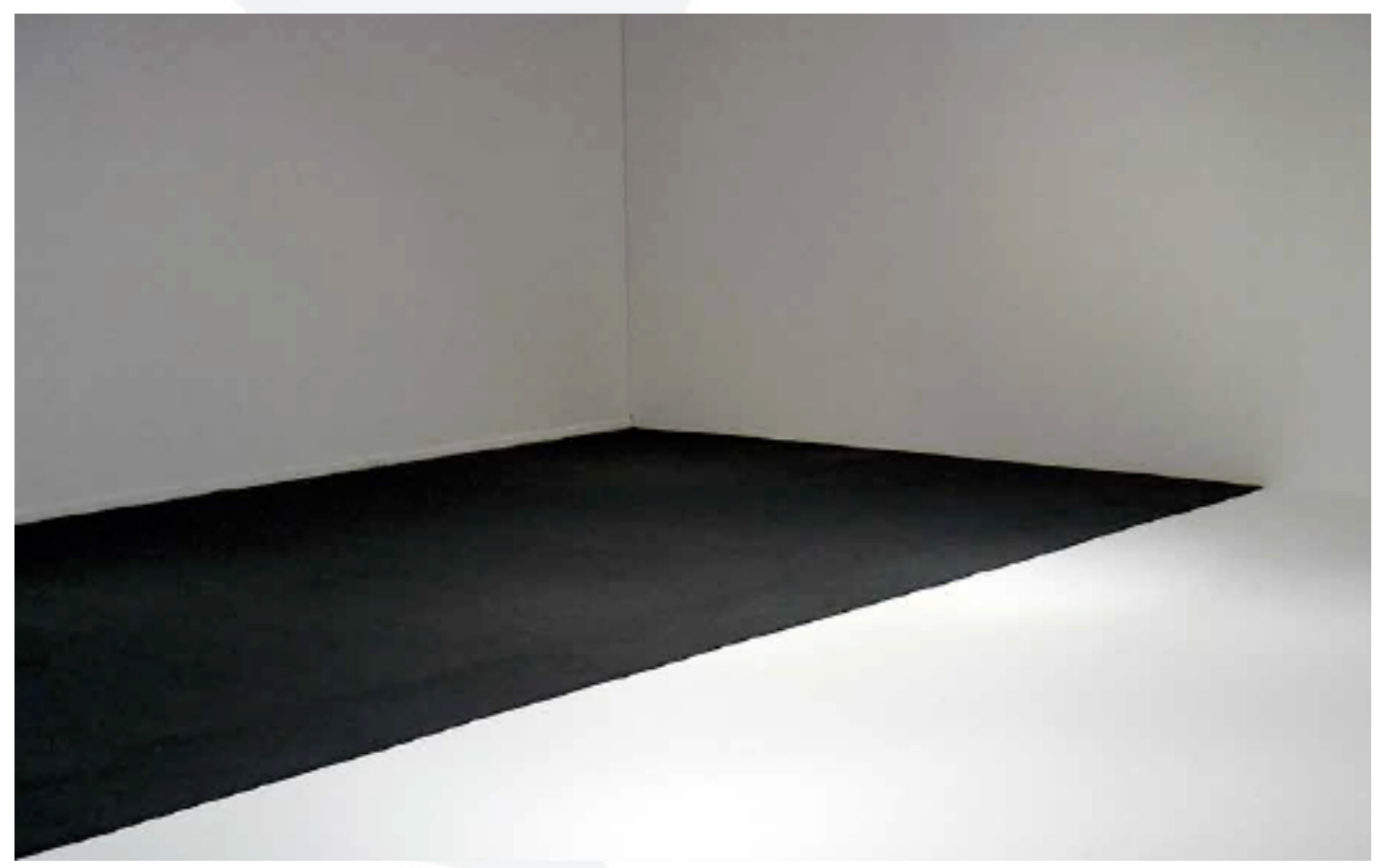

Figura 4: Teoria das Bordas, 2008. Funarte, Brasília Fonte: Portfólio Lais Myrrha

Uma sala é dividida geometricamente em dois lados. Um deles tem o chão coberto por uma espessa camada de granitina preta e o outro é coberto pela mesma quantidade de granitina branca. A granitina é o pó que sobra das pedras depois que trituradas

Deste modo, assim que as pessoas começam a percorrer a sala desta instalação artística os grãos se deslocam, os lados se misturam, as bordas se borram e os limites se diluem devido a insistência das ações que percorrem a 
instalação, fazendo com que o aspecto maniqueísta e geométrico se desmanche e a imagem resta em cinza.

Teoria das bordas (2008) é sobre política e sobre história. Discute a construção dos lugares por meio de sua corrosão, ou melhor, da transfiguração - uma vez que as duas imagens iniciais desaparecem para formar uma terceira (imagem tão impermanente, esta, quanto pode ser uma coleção de areias) ${ }^{1}$. A instalação refere-se ao rastro no momento de formação e desaparecimento das imagens. A imagem-dialética; A imagem representação e apresentação; A imagem condenada ao desaparecimento.

Segundo a própria artista (2007), esta obra destaca algo fundamental de sua maneira de pensar revelando o constante desejo de reconfiguração dentro de seu trabalho por conta da materialidade: a pedra - nesta obra transformada em pó-, foi um material recorrente em seu percurso ( no que diz respeito as obras comentadas nesse artigo). Para ela, a "[...] utilização desse material não é uma premissa, um ponto de partida" e sim uma espécie de lugar ao qual ela retorna com frequência, "mas nem sempre de bom grado" (p.18).

\section{O TEMPO É A MATÉRIA DAS COISAS}

Uma das primeiras inquietações apresentadas na dissertação de mestrado realizada pela artista-pesquisadora Lais Myrrha (2007) diz respeito às cidades. Por meio da citação de um conto de Ítalo Calvino retirado do livro As Cidades Invisíveis (2003), Myrrha compreende que, conforme o próprio título do livro sugere, há uma ordem invisível que governa a cidade e seu processo de construção é interminável. As cidades invisíveis de Calvino, aproximadas à teorias da linguagens, introduz também a ideia de que a palavra e o discurso (marcado por enunciados que o antecedem e sucedem, numa troca constante de sentidos) constroem espaços físicos e sociais.

\footnotetext{
${ }^{1}$ Referência ao ensaio/conto de Italo Calvino escrito em 1975 e publicado no livro homônimo junto a um conjunto de outros ensaios, pela Companhia das Letras em 2010.
} 
A construção de um discurso, que envolve a inter-relação entre sujeitos, implica mudanças no espaço social - montagens e remontagens -, nos indicando que as cartografias são realidades sociais, e não naturais, podendo assumir diversas configurações possíveis. É uma noite estrelada.

Marco Polo, protagonista do livro de Calvino, pergunta porque a construção da cidade de Tecla demorava tanto tempo, ao que lhe respondam:- 'Para que não comece a destruição'. Não satisfeito, continua: 'Qual o sentido de tanta construção? Qual o objetivo de uma cidade em construção senão uma cidade? Onde está o plano que vocês seguem, o projeto'? Mas suas questões não são de imediato sanadas, é preciso esperar o fim da jornada de trabalho que cessa ao por-do-sol.'A noite cai sobre os canteiros de obra. É uma noite estrelada. - Eis o projeto dizem'. (MYRRHA, 2007, p. 16 APUD CALVINO, I., 2003)

Seguindo esta linha de raciocínio e pensando a cidade como uma forma de linguagem e materialização de discursos (que são vinculados ao poder) ${ }^{2}$ é possível compreender como Benjamin fez de uma cidade uma arqueologia material colocando a história (como disciplina) em processos contínuos de movimentos. A história não mais apoiada em um ponto fixo, mas sim na esperança de recomeços (DIDI-HUBERMAN, 2015, p.114), assume o tempo anacrônico e revela lacunas das narrativas urbanas. Revela rastros, vestígios, restos, contrapontos.

[...] coexistências de diferentes tempos estão evidentes na materialidade da própria cidade, uma vez que no tempo do 'agora' estão presentes as sobrevivências do 'outrora', sobrevivências, por vezes, de futuros não realizados, mas não de um passado materializado que segue uma cronologia linear [...] (JACQUES, 2018, p.223).

É pensando nas coexistências e nas ininterrutpas construções narrativas que Lais Myrrha direciona sua produção para desestabilizar o entendimento de conjuntos de fenômenos naturalizados por acordos sociais. Movimentada pela desconfiança e desejo de questionar estruturas de poder, Lais Myrrha investiga o que chama serem instrumentos de sabedoria que constroem nossa

\footnotetext{
${ }^{2}$ Segundo Michel Foucault (1996), a produção de discursos é controlada, selecionada e redistribuída por certo número de procedimentos que tem por função conjurar seus poderes e perigos, dominar seu acontecimento aleatório, esquivar sua pesada e temível materialidade (p.9). Portanto, as interdições que atingem o discurso revelam sua ligação com o desejo e poder (p.10)
} 
experiência por meio do lugar físico. Instrumentos de sabedoria advindos de uma vontade da verdade, se pensarmos com Michel Foucault (1996), que constitui um sistema de exclusão.

Ora, essa vontade de verdade, como os outros sistemas de exclusão, apoia-se sobre um suporte institucional: é ao mesmo tempo reforçada e reconduzida por um compacto conjunto de práticas como a pedagogia, é claro, como os sistemas dos livros, da edição, das bibliotecas, como as sociedades de sábios de outrora, os laboratórios hoje. Mas ela é também reconduzida, mais profundamente e sem dúvida, pelo modo como o saber é aplicado em sociedade, como é valorizado, distribuído, repartido e de certo modo atribuído (FOUCAULT, 1996, p.17).

Tais elementos de saber podem ser dicionários, mapas, bandeiras, hinos, jornais, notícias de televisão, discursos de poder, cidades e edifícios. É por meio desses dois últimos elementos que a artista mais se aproxima da arquitetura, tensionando relações entre tempo, espaço, história, memória e ruína. Pensando significações, técnicas, poéticas e materialidades, muitos de seus trabalhos revelam sua linha de raciocínio (ou parte dela) que abarca a impermanência dos objetos por meio de sua materialidade tomada como alegoria da impermanência da imagem.

Portanto, é fundamental para a coerência do processo criativo e de pesquisa de Myrrha que o próprio material que constitui a obra comunique as narrativas por meio de sua dimensão física e tectônica. É a partir das deslocamento da imagem do objeto que ela desestabiliza discursos definidos a priori e permite um alargamento das possibilidades imaginativas. Isto posto, além das já comentadas Teoria das Bordas (2007) e Mitos de Origem (2012), iremos analisar neste ensaio as obras Dicionário do impossivel (2005), Pódio para ninguém (2010/2013), O Passo da História (2014), Descontinuidade pelo tempo (2017) e Cálculo das diferenças (2017).

Demosntraremos, ao abordar conceitualmente construções de imagens narrativas e historiográficas por meio do estado material (e de sua impermanência), como a artista se aproxima da área da arquitetura e do urbanismo. 
emergência ou na morte dos objetos, parece não the interessar o instante da sua permanência. Sua obra nos oferece o resultado de uma meditação constante sobre o tempo intermitente mensurado pelos relógios e a fugacidade de experiência vivida (MELENDI, 2013, p. 9).

\section{Pódio para ninguém}

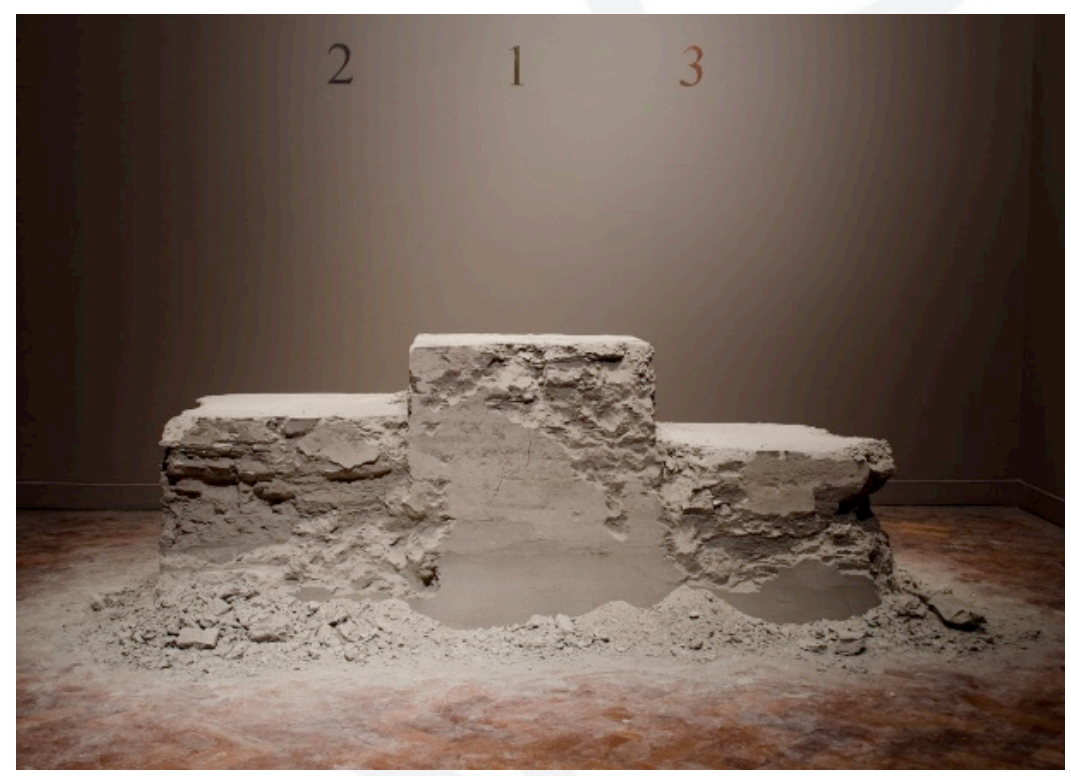

Figura 5 : Pódio para ninguém, Zona de Instabilidade. Caixa Cultural São Paulo. Fonte: Portfólio Lais Myrrha. Imagem de Fernando Cohen.

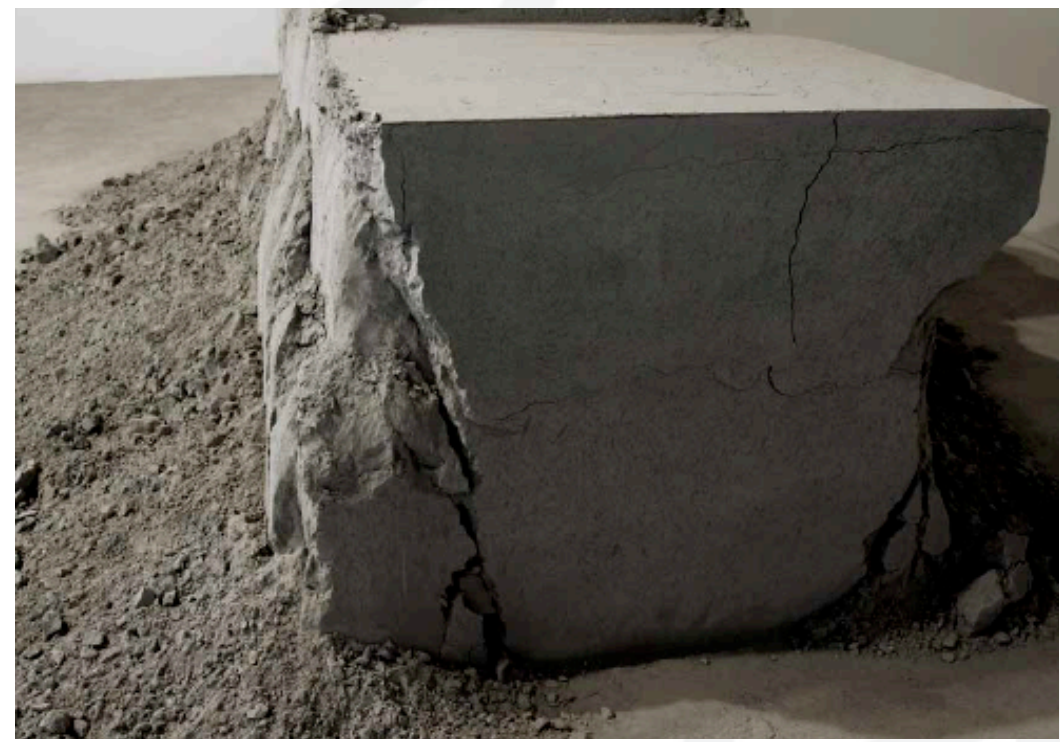

Figura 6: Pódio para ninguém (Detalhe), Zona de Instabilidade. Caixa Cultural São Paulo. Fonte: Portfólio Lais Myrrha. Imagem de Fávio Lamenha 
Para Maria Angélica Melendi (2013), o Pódio Para Ninguém expressa muito bem a tensão entre a matéria, objeto e seu desaparecimento. Construído com $1500 \mathrm{~kg}$ de cimento prensado sem liga, a construção não tem autossustentação e, assim que deformada, cede. É apenas sobre seu desmanche parcial que o pódio se sustenta, se estabilizando em maior permanência enquanto ruína. É preciso ceder para acomodar e, sobre esse pódio, "ninguém será premiado nunca" (p. 10).

O símbolo do pódio propõe diversas relações entre forma, substância, tectônica e função. Discutindo elementos que suportam a mensagem arquitetônica com significados abertos, a obra poderia indicar a compreensão da própria arquitetura como materialização de discursos de poder por meio do uso de gramáticas caras ao universo da competitividade esportiva, mas que podem ser projetados em outros modos de organização social. Competição e esporte são duas palavras que teoricamente não combinam, uma vez que a palavra esporte em francês desporter significa distrair-se e divertir-se, originária do grego des, que significa fora fora/embora e porter, que significa levar/carregar. Enquanto competitividade traz a ideia de luta e rivalidade. No entanto, atualmente, é difícil pensarmos no esporte (profissional) sem que venha em seu bojo a noção de competição.

Além da competitividade esportiva, a questão hierárquica da arquitetura poderia se dar pelo fato do uso do cimento, por exemplo, ser um elemento simbólico cuja tectônica é bastante presente na formação da arquitetura moderna brasileira, tida como a arquitetura oficial do Brasil na busca de moldar um determinado imaginário coletivo. Ou ainda, o pódio poderia representar um sistema de valoração e premiação fazendo uma crítica à sociedade neoliberal que tem a competitividade como valores (des)estruturantes dentre os quais a artista poderia estar apontando para uma falsa promessa do mito da meritocracia. 


\section{Cálculo das diferenças}

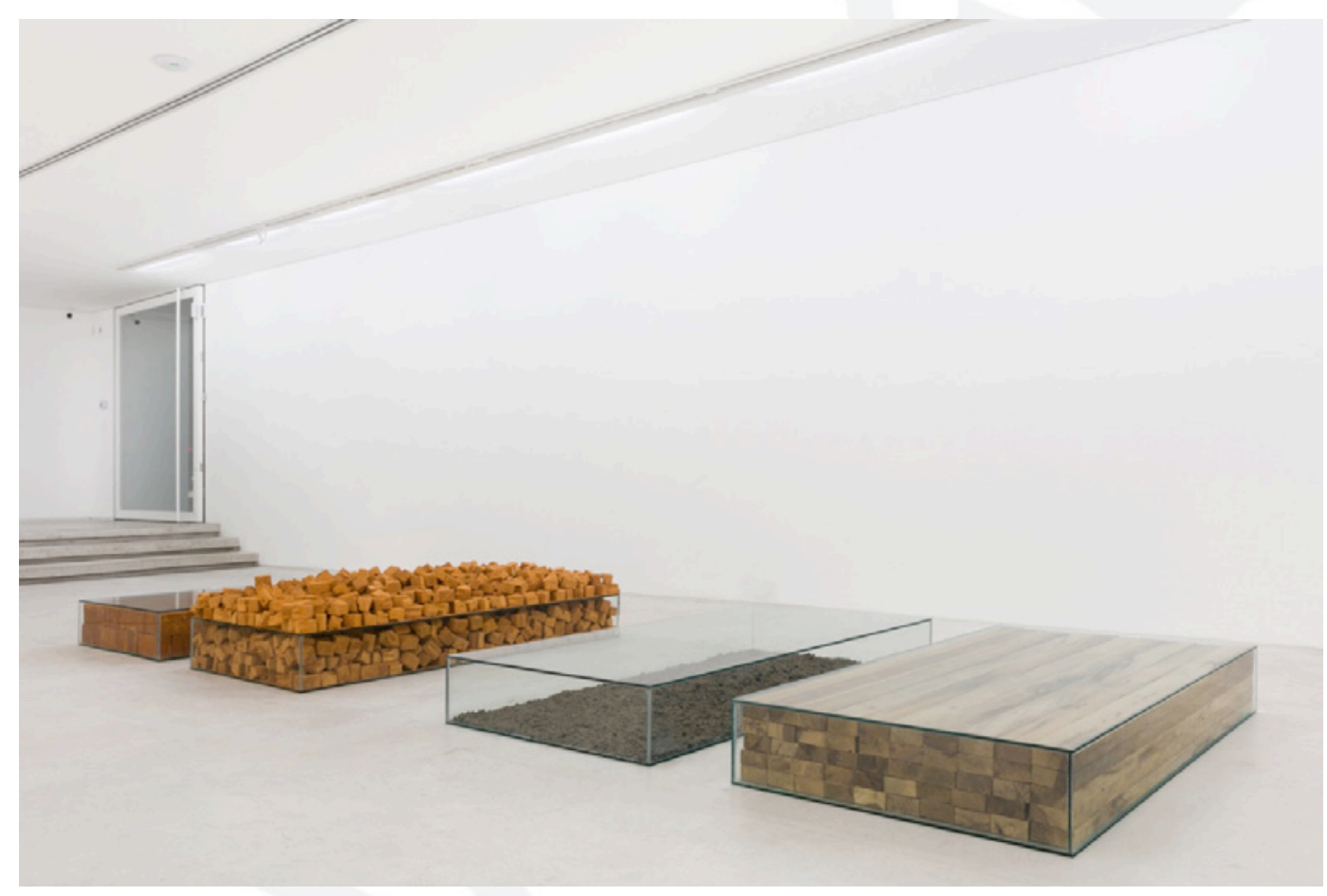

Figura 7: Cálculo das Diferenças, 2017. Parte da Mostra coletiva Hiato (SIM GALERIA) com curadoria de Michele Sommer Fonte: Porfólio Lais Myrrha

A obra Cálculo das Diferenças também trata da impermanência do material, mas em outros aspectos. Neste caso, a artista traz a ideia do desmanche do material em determinada condição física que, por sua vez, se transforma em outro estado de condição física. São quatro módulos de vidro, dois contendo tijolos e dois contendo madeira. Inicialmente, os dois materiais em estado íntegro têm o mesmo volume - que é o definido pelo módulo.

Um dos módulos é ocupado com tijolo em matéria preservada, e o outro enquanto matéria arruinada. $\mathrm{O}$ mesmo acontece com a madeira. Se um dos módulos comporta a madeira em matéria preservada, o outro a comporta em matéria arruinada. É curioso notar a diferença de volume ocupado pelos materiais em cada um dos estados: enquanto a madeira destruída (no caso queimada) ocupa uma parcela muito inferior ao volume disponível inicialmente, o tijolo demonstra o contrário em sua mudança de estado: 
quando destruído, seus fragmentos desobedecem o limite do módulo e aumentam de volume.

É evidente que a diferença acontece tanto pelo motivo de se tratar de materiais distintos, como também pelo fato de terem processos de destruição igualmente distintos. Se um deles é queimado e transformado em cinzas, o outro é quebrado e transformado em fragmentos soltos. Com essa obra, portanto, "Myrrha desestabiliza as convenções materiais libertando-as dos seus confinamentos e desvelando, assim, a desordem frente à suposta ordem - e verdade - que reside em projetos construtivos (e arquitetônicos também)" (SOMMER, 2019, s/p).

A artista investiga a disposição de espaço ditada pelo módulo envólucro em diálogo com as diversas possibilidades de ocupação desta definição de acordo com a diferença de estado da matéria - que depende também dos estímulos externos aos quais a matéria foi submetida (ela esta sofrendo golpes que a quebram? Está sendo queimada? Molhada? Congelada? Evaporada?).

Intriga também pensar no envólucro cujo formato e tamanho poderiam ser o de um caixão, um túmulo: o confinamento em seu último estado, mas também elemento presente nos ritos de passagem. No entanto, diferentemente do túmulo, que é opaco, a artista faz uso de um material translúcido que permite vislumbrar essa experiência de limiar. Um envólocro que é, ao mesmo tempo, confinamento e experiência de limiar como uma tentativa de tornar visível o momento de morte do objeto, de intervalo, "a linha de fratura entre as coisas" (DIDI-HUBERMAN, 2015, p.126). Eis a imagem dialética; Representação e apresentação; Aparecimento e desaparecimento. 


\section{O passo da história}
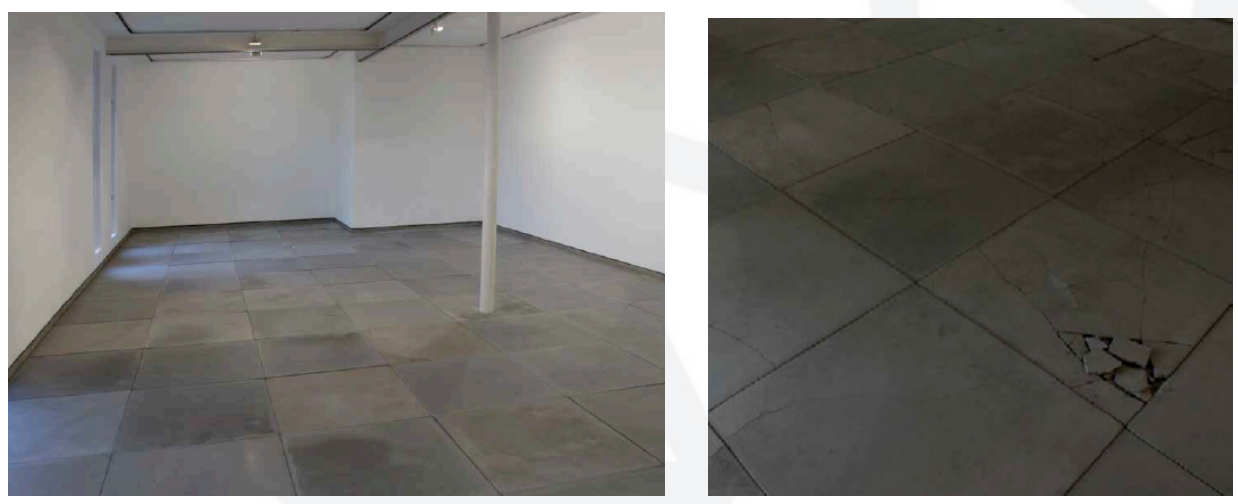

Figura 8 e 9: O passo da História (montagem de instalação). Galeria Manoel Macedo, Belo Horizonte. Fonte: Portfólio Lais Myrrha

Em O passo da história a artista questiona os rumos da historiográfia tradicional. Sua lógica de (des)construção é similar ao Pódio para ninguém, contudo, seus resultados e mensagens podem ser outros. A artista forra uma sala com placas de cimento de $80 \mathrm{~cm} \mathrm{X} 80 \mathrm{~cm}$ sem assentá-las no chão. Deste modo, à medida que as pessoas entram na sala e começam a se movimentar sobre o piso as placas vão se quebrando pouco a pouco. 0 piso (a imagem realizada no passado) se modifica com cada passo no presente. Tal imagem pode se abrir como uma analogia a um terreno urbano, construído de determinada maneira e produzindo certa ocupação, mas também sendo produzido pelas ocupações que desenham ramificações em seu tecido.

Nesse sentido, podemos pensar os esforços da artista como sendo caraterísticos de uma arte historiográfica que operam, segundo Ana Pato (2017), por meio de operações historiográficas. A partir de Michel de Certeau (2013), Pato explica que estas operações se referem “[...] à combinação de um lugar social, de práticas científicas e de escrita" (p.18) de modo a olhar criticamente para como a história (e os espaços) são escritos. Por sua vez, partindo dessa afirmação, Giselle Beiguelman (2019) discorre sobre o que ela 
identifica como um impulso historiográfico ${ }^{3}$ nas artes do Sul Global que se manifestam com o objetivo de realizar "[...] uma sondagem idiossincrática da história do país" (p.4). Ou seja, se quisermos, essa obra parece instrumentalizar um possível olhar crítico para os modos como as cidades brasileiras, por exemplo, são construídas: os nomes das ruas, os monumentos, o traçado urbano ${ }^{4}$ - tendo em visa que as placas dispostas formam um gride ${ }^{5}$ que é, de algum modo, desfeito

\section{Descontinuidade pelo tempo}

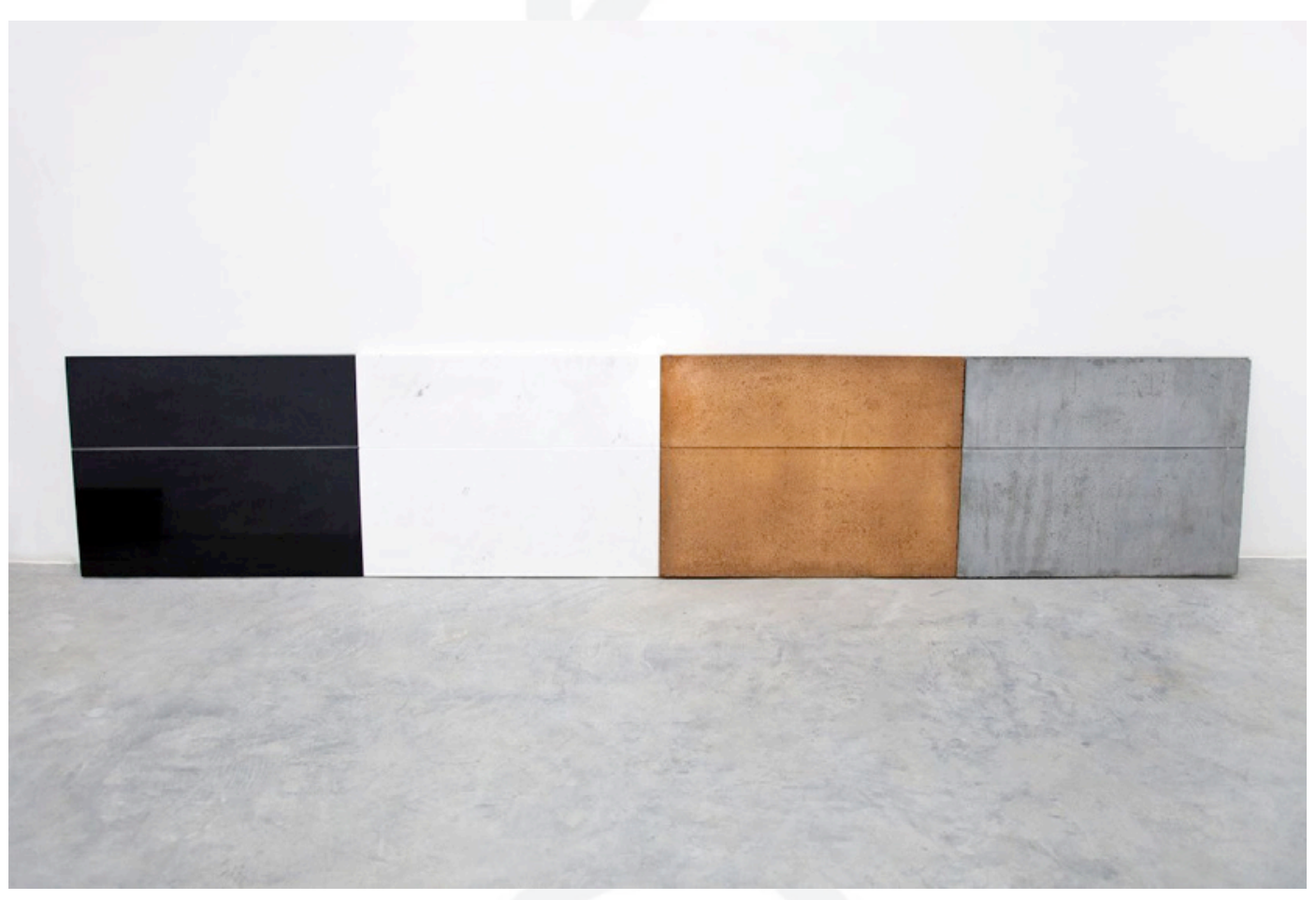

Figura 10: Descontinuidade pelo tempo (basalto, mármore, taipa e cimento)-

Galeria Athena, 2017

Fonte: Portfólio Lais Myrrha

\footnotetext{
${ }^{3}$ Artistas brasileiras e brasileiros como Rosana Paulino, Paulo Nazareth, Tiago Sant'anna, Rosangela Rennó, Jaime Lauriano, Clara lanni, Igor Vidor, Bianca Turner e Ícaro Lira tem, eu seu conjunto de obras, uma série de produções que caracterizam como arte historiográfica.

${ }^{4}$ Existem outras obras da artista, que não serão comentadas neste ensaio pelo fato deste se remeter a questões conceituais e metodológicas, que tratam mais diretamente da questão dos apagamentos históricos nas construções da cidade. É o caso de Geometria do Acidente (2014).

${ }^{5}$ Gride como os quais as cidades modernas (planejadas) são projetadas e imaginadas.
} 
Também refletindo conceitualmente quanto as definições de história, linhas do tempo e quanto a impossibilidade de uma cronografia universal, a artista lança mão dos materiais para mostrar a relatividade do tempo ante a determinadas condições. Quatro placas são dispostas lado a lado: uma de basalto, a segunda de mármore, seguida de taipa e, por fim, o cimento. Unindo as quatro placas a artista sulca o traço e, apesar da mesma intensidade de quem o realiza, cada material tem uma reação diferente, uma vez que cada um deles tem uma especificidade de resistência própria. Deste modo, o rastro decalcado não aparece da mesma maneira em todo o trecho apesar de ter a mesma profundidade em todas as placas.

Esse traço pode ser entendido enquanto metáfora para a linha do tempo, e tal ação demonstra a impossibilidade de uma linha universalmente definida por uma força externa a propriedade de cada um dos corpos sobre os quais ela atua pelo simples motivo de os materiais não possuírem o mesmo tempo de erosão. Sendo assim, os materiais não reagem da mesma maneira, uma vez que a textura e as cores são distintas umas das outras de modo com que o mesmo traço apareça mais ou menos devido a cada materialidade. Os rastros, portanto, além de serem diferentes, se destacam de maneiras diferentes. 0 movimento de descontinuidade pelo tempo mostra a descontinuidade da história - que não é algo fixo, insiste a artista, nem mesmo uma simples narrativa causal.

Dos quatro materiais que constituem essa obra, depois da Taipa, o mármore é o mais frágil (no sentido de ser o que sofre mais modificações com menor ação de força em menos tempo). Tal material é usado na obra Dicionário do Impossivel, no qual a artista também trata da reação da impermanência da imagem de acordo com a materialidade. 


\title{
Dicionário do impossível
}

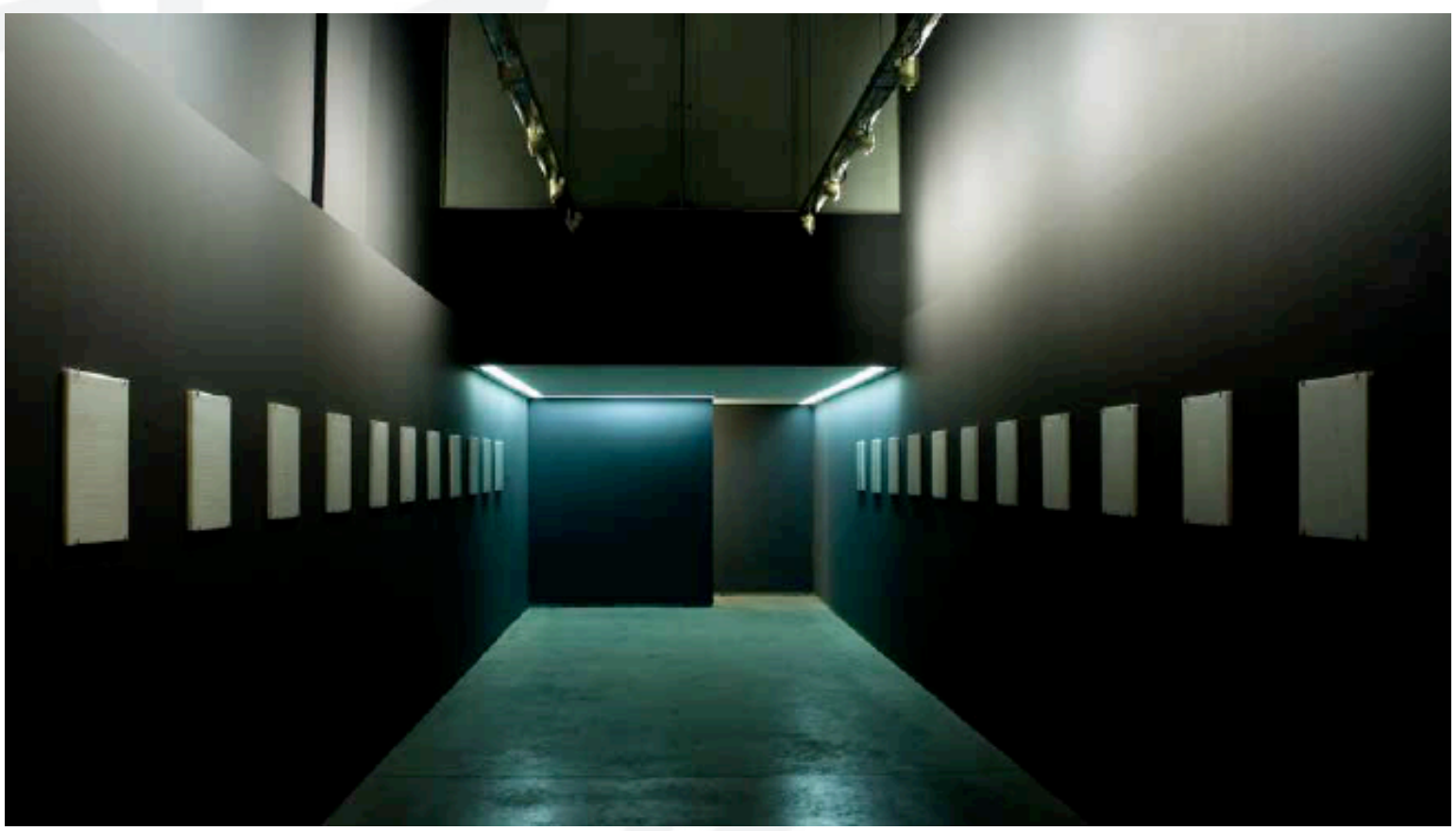

Figura 11: Dicionário do Impossível, 2005 Fonte: Portfólio Lais Myrrha. Imagem Eugênio Sávio

Esta instalação é formada por 22 placas de mármores sobre as quais estão gravadas com jato de areia palavras ou expressões extraídas de um dicionário da língua portuguesa e que são iniciadas pela letra $i$ do alfabeto. Com esse conjunto a artista a aponta para a impossibilidade de um dicionário como elemento resolvido (estável, finalizado e finito).

\begin{abstract}
Seja porque tais léxicos representam conceitos apenas possíveis de apreendermos abstratamente - como a expressão latina in aeternum e a palavra infinito - seja porque indicam algo que se encontra num plano ideal como, por exemplo, o verbete indefectível (aquilo que não pode ser feito) (REBOUÇAS, 2013, p.9).
\end{abstract}

Aqui, Myrrha está diretamente se voltando para teorias da linguagem pensando a língua enquanto sistema de valor que atua de acordo com determinadas normas-, e de suas relações entre materialidade, tectônica e produção de discurso. Provocando o incontestável do dicionário como instrumento de saber, Myrrha o imprime em um material que vai se desgastando com o tempo de modo com que suas inscrições vão 
desaparecendo ${ }^{6}$. A imagem, como viemos discutindo até aqui, é impermanente e impossível de se compreender dentro de um domínio dicionarizado.

\section{CONSIDERAÇÕES FINAIS}

Retomemos agora a Teoria das Bordas e imaginemos que esse pó é advindo da destruição de todas as obras de Lais Myrrha, conforme apresentado no prólogo em reflexões da própria artista. Uma ficção em que uma crise atingiria toda a sua produção, desconfigurando todos os seus arquivos. Dentro desse lugar imaginário das bordas, suas obras seriam reconfiguradas a partir do pó, como se a rigidez do material usado anteriormente fosse simbolicamente destruída dando origem a uma espécie de anti obra que compõe novas e outras possíveis configurações segundo a movimentação externa a ela, os passos.

Pois bem, se em Teoria das Bordas a artista faz essa reflexão das infinitas configurações de imagens ao rés do chão, em Mitos de origem (também comentada no prólogo), ela faz a especulação por meio de uma cartografia do céu. Uma poeira de pedras, outra poeira estelar: duas imagens se desdobram infinitas. Ambas são questão de política e de história e fazem parte do objetivo incansável da artista de desnaturalizar o sistema de representação do saber (seja do tempo, seja do espaço). Tal busca por diversos pontos de narrativa nos lembra afirmações de Ailton Krenak a respeito de sua provocação que afirma a possibilidade de adiar o fim do mundo:

Nosso tempo é especialista em criar ausências: do sentido de viver em sociedade, do próprio sentido da experiência da vida. [...] E está cheio de pequenas constelações de gente espalhada pelo mundo que dança, canta, faz chover [...] E a minha provocação sobre adiar o fim do mundo é exatamente sempre poder contar mais uma históra. Se pudermos fazer isso, estaremos adiando o fim. (KRENAK, 2019, p.27)

\footnotetext{
${ }^{6} \mathrm{O}$ trabalho foi realizado em 2010 e atualmente, segundo a artista, o texto já quase não aparece mais.
} 


\section{BIBLIOGRAFIA CITADA}

CALVINO, I. Coleção de areia. São Paulo: Companhia das Letras, 2010.

CALVINO, I. As cidades Invisíveis. São Paulo: Companhia das Letras, 2003.

BEIGUeLMAN, G. Impulso historiográfico. São Paulo: Peligro edições, 2019.

DIDI-HUBERMAN, G. Diante do tempo:História da arte e anacronismo das imagens. Belo Horizonte: Editora UFMG, 2015.

FOUCAULT, Michel. O corpo utópico, as heterotopias. São Paulo: Editora N-1, 2013.

FOUCAULT, Michel. A ordem do discurso. Aula Inaugural no Collège de Frange, pronunciada em 2 de dezembro de 1970. São Paulo: Edições Loyola, 1996.

JACQUES, Paola Berenstein; DA SILVA PEREIRA, Margareth (Org.). Nebulosas do pensamento urbanístico. Salvador: Edufba, 2018.

KRENAK, A. Ideias para adiar o fim do mundo. São Paulo: Companhia das Letras, 2019.

NORA, Pierre. Entre memória e história: a problemática dos lugares. Trad. Yara Aun Khoury. Revista Projeto História, São Paulo, v. 10, p. 7-28, 1993.

MELENDI, Angélica. Uma Cronografia de espectros in: Uma cronografia dos DESMANCHES. Trabalho realizado pelo Edital Bolsa Funarte de Estímulo à produçãoo em Artes Visuais, 2012.

MYRRHA, Lais. Sobre as possibilidades da impermanência: fotografia e monumento. Dissertação (mestrado) - Escola de Belas Artes, Universidade Federal de Minas Gerais; Belo Horizonte, 2007.

PATO, Ana M.-Arte contemporânea e Arquivo: como tornar público o arquivo público? (tese de doutorado) Faculdade de Arquitetura e Urbanismo, USP, São Paulo, 2017.

REBOUÇAS, J. Zona de Instabilidade. Catálogo da exposição Zona de Instabilidade de LaisMyrrha, realizada na Caixa Cultural São Paulo; 2013.

Fontes eletrônicas e sites

DIDI-HUBERMAN, G. Remontar, remontagem (do tempo). Chão da Feira, n. 47, BeloHorizonte, jul. 2016. Disponível em < https://chaodafeira.com/wpcontent/uploads/2016/07/cad_47.pdf > acesso em 5 de jun.2019. 
MYRRHA. Lais: Portfólio (2019). Disponível em $<$ https://www.simgaleria.com/arquivos/1554233115-portfolio-laismyrrha.pdf> Acesso em 1 de dez. 2019.

SOMMER. M: Hiato (2019). Disponível em <https://www.simgaleria.com/exposicoes/hiato> Acesso em 3 de jan.2020.

\section{LISTA DE FIGURAS}

Figura 1 - Mitos de Origem pág.: 34

Figura 2 - Mitos de Origem pág.: 34

Figura 3 - Mitos de Origem pág.: 34

Figura 4 - Teoria das Bordas pág.: 36

Figura 5 - Pódio para Ninguém pág.: 40

Figura 6 - Pódio para Ninguém pág.: 40

Figura 7 - Cálculo das diferenças pág.: 42

Figura 8 - O passo da História pág.: 44

Figura 9 - O passo da História pág.: 44

Figura 10 - Descontinuidade do tempo pág.: 45

Figura 11 - Dicionário do impossível pág.: 47 